\title{
A Conversation With Patricia Hampl
}

WE HAD THE PLEASURE of interviewing Patricia Hampl during March of 1993, when she visited Iowa City to give a reading, and to meet with students in the nonfiction writing program where she will be a Visiting Professor in the spring of 1994. She is the author of two books of poems, Woman Before an Aquarium and Resort and Other Poems, as well as several books of memoir and meditation: A Romantic Education, which chronicles the convergence of the personal and historical in a journey to Prague; Spillville, about Antonin Dvořák's stay in the Iowa farming village during the summer of 1893; and most recently, Virgin Time, the story of a quest to discover the nature of faith, one which takes her from Italy to the coast of northern California where she discovers the silence of prayer. A 1990 MacArthur fellow, she teaches at the University of Minnesota and lives in her native St. Paul.

The interview took place on a typical raw, windy March day in David Hamilton's apartment. We sat sipping coffee, tea, and eventually, red wine, and munching on sandwiches at David's round oak dining table as we talked.

TIR: We heard you've been working on your first screenplay, an adaptation of your book, Spillville. How do you like writing for the screen?

$\mathrm{PH}$ : It's the Hatha Yoga of writing-cleansing and clarifying. Maybe it's better for a poet to try screenwriting than for a novelist. Because poets know about silences and echoes, letting the echo carry the message. When you write "Exterior / Day / Prague" at the top of a screenplay, there's a lot more you don't do. And there's something, at first, annoying about it-you want to say, I'll tell you what they're wearing, and I'll tell you how they feel. Then you suddenly feel this crazy liberation. It's very, very-I wouldn't say precise, it's elliptic. You put a stroke down, and you put another stroke down. . . . Always the producer's saying to me, "Well, this is fine, but we won't really need that, the set designer will do that," or-" There are other people who are going to decide how that's going to

Jocelyn Bartkevicius, David Hamilton, and Mary Hussmann were the interviewers. 
look." There are some key places in the screenplay where I set the stage-whenever there are beginnings, I might say, It's springtime, there are lilacs, make sure there are lilacs-but I don't do a lot of scene-setting. TIR: I would think it would be hard to let go of what you have inside, what you see inside, and trust others to just make it so.

$\mathrm{PH}$ : Well, the truth is, the others don't exist yet, and luckily this process happens sequentially. I'm alone writing or I'm talking with Robin Burke, the producer, and I make all these decisions with her. At some point I may see these decisions erased, and dashed, and I will experience whatever I experience at that time. But right now I'm a student, I'm learning. This is the exciting part. Robin may tell me, You don't need that, or I'll tell myself, Don't do that-but it's still here, it's still in my mind. Just because I don't need to write what the room looks like doesn't mean I don't see the room. In some ways, because it remains internal, not constellated in language, the fluency of the image is more powerful. And the other thing I notice in writing a draft is how crude a lot of the dialogue is. I have someone walk into a room, and virtually have him say, "I feel sexually attracted to you." I say things almost that bluntly because I need to know what that person is feeling. Later I have to go back and create a scene that expresses that. The first thing I did was a "through-line," which is essentially getting from the beginning to the end and making sure there is a final destination. Dramatic writing. I didn't know anything about this. But Robin kept saying, Now don't stop there, just keep going. Like a good horse, I would keep going until I got to the stable again. So a lot of the writing in this first draft looks comically crude to me. When we reread it in New York last week I got hysterical at some of the ludicrous things I'd written. Yet they were place-holders for themes. They weren't wrong, they were just impossible to use. They were psychologically correct, but artistically ridiculous.

TIR: How much do you expect to be diverted from that through-line as you fill out the places in it?

PH: Of course the line is going to get a wiggle to it. And that's good, it should have a sense of movement. For instance, I felt that I had to create Ellen Spencer, a fictional character, in order to create a voice for the movie, and I suggested we put the whole thing in a memoiristic envelope. So I have Ellen Spencer actually writing this in 1938, which is a very eloquent year in Czech history because it's the year Hitler invaded, and it was the end of The 
First Republic. She's an old woman at that time. We have her doing a voice-over, the whole story is held within her consciousness.

TIR: And that puts your stamp as a memoirist on the movie.

PH: Yes. The thing that I know, that I work with best, is voice-I would have to be told if I'd created a plot.

TIR: Thinking about the character of Ellen brings to mind an essay you wrote called "The Need to Say It," in which you refer to your Czech grandmother in A Romantic Education, and to Donnie, the contemplative nun in Virgin Time, as the main characters of each book. As a reader, I was surprised at that remark, because I did not ever get a sense of those two as central characters. I had assumed that the central character was you. Is Ellen similar? Would you tell us a bit about narrative roles in your books?

PH: I think those two characters are actually the heroes of those books. In a way, I am their minion. I make a distinction in memoir between the protagonist and the hero. I am the protagonist of those books, but I am not the hero-the hero is a figure of commitment and triumph, or of mythic power. I'm the traveler, the protagonist, who carries the question that the hero actually lives. If I've done it right.

TIR: So the protagonist carries the quest that you say is necessary to a memoir?

PH: Yes. The protagonist carries the quest. The hero or icon figure is what it's all about, is the character who is in a way living the very thing, oftentimes, that this protagonist is looking for. The hero isn't necessarily an appealing or honorable figure, though I think both Donnie and my grandmother are. But in my current favorite memoir, I Had a Father by Clark Blaise, the hero is the father-and he's a fraud and a whole bundle of fascinating trouble.

TIR: The quest can be a question about the hero?

PH: That's perfect. The word memoir says "memory, memory, memory," says "the past." But the genre, if it's alive, needs to have the urgency of forward movement. There has to be a reason why we're going to the past. And it can't just be tourism. It must be a necessary trip. We all know that the future is what's necessary, is what's coming, not the past, in spite of its adhesive power. The past has to be brought into the future by the art of writing. So that's why this protagonist is so necessary. You have to have somebody who's looking for something. And in a memoir, this somebody has to be oneself. 
I came to this in a very flat-footed way in A Romantic Education. I wrote ninety pages, let's say, of a biography of my grandmother, and it was sincerely meant to be a biography of this woman I considered fascinating. She was the main character, the hero. I wrote away, and ended up with eighty or maybe ninety pages of the dullest prose yet committed to paper. I couldn't understand why it was dull. I couldn't understand why it was lifeless. I put it away. About a month later I wrote a description of my grandmother's garden, out of love for that garden. In a sense a truly memoiristic thing, a commemorative impulse, a retrospective: I want to be in that garden, it doesn't exist anymore, I'm going to write it. I did the same thing about her Sunday dinner. I called these two pieces sketches, and I put them away. But I knew one thing when I put them away, and that was that they weren't dead, they were alive. Whether they were good, or bad, was not the point. They were alive, and the other ninety pages were dead. And somehow or other, over a period of time I began to realize why one was alive and one was dead. It was because I had used myself as a protagonist in those two sketches. There was a character there, and the character was me.

It was not good news to me that I had to write this in the first person, because I had a lot of prejudice against the first person. It seemed egotistical, and self-absorbed, and I really felt like putting a sign up that said, I'm sorry, I can't help myself, I don't want to do this either. I don't know anybody who grew up saying, I want to be a memoirist when I grow up. You want to be a poet, you want to be a novelist - You don't think of memoir as a real genre. But I knew that I could sustain the story, and I had never known that before, and that was irresistable. Once I knew I could sustain the story to the end, how could I resist writing it in the first person?

TIR: Well, early on in A Romantic Education you write about memoir as living history, and since it comes so early, I felt that it was a kind of disclaimer for the rest of the book.

PH: It comes early in the book; it didn't come early in my writing the book. I wrote that towards the end, and it definitely is a defensive remark. It's not only defensive, it is elbowing room for the genre. Not just for me, but for this genre. At that point I knew that this thing was a memoir, there was no way around it. It wasn't a biography, and I wasn't going to be able to call it a novel.

I can remember when the book came out, I was introduced for the first time to the marketplace of writing. Because when I published my first 
book, a collection of poems, there was no real marketplace, it was issued, more than published. I had never met a salesperson or any of that. So when I was introduced to the publisher's sales representative for the upper Midwest, she came bounding into the room and said, "Love your book, but I don't know how to pitch it." And of course I was heartbroken. I wanted her to sit down and talk to me about the book, and.... Well, what she was saying was, "I have about thirty seconds in a bookstore to say to a buyer, 'Here's what this book is, here it is, and how many do you want to buy for your bookstore." And she was telling me that in thirty seconds she could not tell anyone what my book was-she couldn't call it a novel, and to say it was a memoir by a 35-year-old woman didn't exactly-And so it was a problem. Ten years later, when it came time to publish Virgin Time, nobody was talking that way anymore. The genre had, in its own modest way, established itself. People knew what such books were, they understood that these books often are travel-based and are first person narratives, and they're part fiction, part essay, but mainly they're stories that you want to read from page one to the final page, if they're done correctly.

TIR: As a reader, I still have trouble finding essays and memoirs, making it understood what kind of books I want to browse. For example, after a local bookstore assured me, over the phone, that they had plenty of copies of Virgin Time, I went in and looked all over the bookstore and couldn't find it. I looked in the sections where they kept E.B. White and other writers I love, but I couldn't find it. I got some help, and it was in BiographyPH: Could've been in Women's Studies, could've been in Religion, could've been in Travel-

TIR: - and that made me want to talk to you about genre. It sounds like you are defining yourself as a memoirist.

PH: When I'm writing those books I'm a memoirist, but I certainly am interested in doing other things, too.

TIR: Well, you brought it into the film as well.

PH: Yes. I fell in love with the first person voice, not, I hope, with my own voice, but all the first person voices in literature. You know, there are two lines from American poetry -I should embroider them on pillows and sleep on one one night, and one the next night. One is Whitman, "I loafe and invite my soul." The other is Emily Dickinson, "This is my letter to the world that never wrote to me." Those two statements are to me the bedrock of our literature, of my experience of our literature. And they're 
both about the first person, they're both about the first person in the world. In many ways, our culture, which took to psychoanalysis so avidly, has a problem sometimes, a puritanical problem, with the first person, even while clinging to it as its natural heritage. I think that a lot of people say, "Me me me, let me out of this me, it's just about being involved in your own psyche." Not that it isn't part of it-it is. But in fact, I think that our more natural association with the first person voice has to do with its relationship to the world. It's a vulnerable narrative stance. There's nothing in the first person that can claim to be "omniscent." I'm not just interested in the memoir, I'm interested in lyric poetry that's in the first person, I'm interested in first person stories, essays in the first person, wherever the first person comes and goes, fades and comes forward. I was reading an essay yesterday by Carl Klaus that compares the beginnings of three E.B. White essays, describing one in which E.B. White is virtually not present, another where he's kind of present, and the third one where the essay appears not to be about the subject but only about himself. So that the first person winks and fades, it comes forward, it gleams and then it seems to disappear. All of that I find really exciting because it's a narrative alternative. It isn't just about genre, it's also about voice.

TIR: You've written a little bit about using the imagination in your memoir writing. Can you say what it is, when you're merging imagination with fact, that drives a piece of writing to the edge of being memoir, say, rather than story?

PH: You mean short story?

TIR: Or novel.

PH: Or, on the other side, what keeps it from being high journalism, or reportage. I think the key is voice. You signal genre by voice. And you might say, well, that takes a very sophisticated reader. Maybe it does, and maybe that's why memoir is a minor genre for our culture. But I think you signal imaginative writing in memoir by making it clear that you're working from memory which is incomplete, which has limitations, and yet you have a desire for completion, which causes the imagination to kick in. Nowhere do I write, This book is only partially fact-I don't signal in that way-but I think that anyone reading A Romantic Education or certainly Virgin Time would know that there are imaginative parts here. The reconstruction of conversations, of dialogue-how accurate could those from the deep past be? Yet don't we agree to understand that they're 
accurate enough? I worked as a journalist, and I love journalism, but the line between genres does blur. And I find that line fascinating, I can't get away from it. I keep meaning to write fiction, I keep meaning to write journalism the way I used to, but I keep doing this thing in the middle.

For years I've followed the various disputes that seem to come up more frequently about the distinction between fiction and "nonfiction." The question about the propriety of Alastair Reid's composite characters in his "Letters" to The New Yorker when William Shawn was still editor; the more recent legal battles of Janet Malcolm and even Joe McGuinness's biography of Teddy Kennedy.

As long as we keep insisting that everything that doesn't have the label "a novel" slapped on the cover is simply nonfiction, we're going to have trouble deciding what the rules are. We have a ruinously simple-minded notion of "nonfiction." The very fact we won't sort out all the various genres sheltering under that oddly negating genre-term is part of the problem. This is a troubling cultural question. But it is one which can no longer be resolved by demanding that works maintain themselves in the labeled bins which we like to think keep art and life, fiction and fact, invention and transcription separate and discrete.

I don't like being lied to, especially not in art. And I find a book like McGuinness's "biography" at least as annoying for what it claims is "imagination" as for how it traduces knowable facts. But we can't keep claiming that "nonfiction" is one simple business. We have to learn to read better, to listen for the clues and nuances of voice. It's in voice that a writer makes the real contract with the reader.

TIR: You mentioned last night that the Italian section of Virgin Time is based on six different trips?

PH: I can't remember, either five or six.

TIR: But it reads as if it's one trip, and the Prague section of $A$ Romantic Education is clearly two trips-you leave and come back-

PH: But I made three trips.

TIR: So did you get braver with your fictionalizations in Virgin Time?

$\mathrm{PH}$ : Yes, I became bolder, less apologetic. More narrative. I also felt -oh, there are a lot of choices-In A Romantic Education I was more didactic. I was trying to get a lot of Czech history in there, and I paused a lot longer for-I wouldn't say personal essays-but more for instructive essays about Czech history. And readers had to soldier through that to get back to the story. 
When I got to Virgin Time I thought two things. One, I want this book to move faster. Just because I want it to. Just because I don't want people to come up to me and say, I'm reading your book, I just read it a little at a time. Which means they will never finish it. I wanted to write one where somebody would say, I finished your book last night. I even wanted, if I could possibly get it, to have someone say, I couldn't put your book down. So I knew that meant I had to get a little more drive going, and I couldn't keep stopping the car as often, you know, for another cup of coffee. That was part of it. Also I felt that the subject matter itself was inherently flat. I mean that as a descriptive statement, not as a qualitative statement. I knew that contemplative life, as a subject, was a plain rather than a peak.

TIR: It doesn't give you an obvious hero.

$\mathrm{PH}$ : And it doesn't give you an obvious tension. In fact, quite the opposite. So I decided I needed to tighten the story, I needed to make the story more staccato and to keep it moving in order that the thing that I was talking about wouldn't sag. You know how it is when you're reading a student's short story and the student will have a character who is just terribly dull, and you'll point this out gently. "Well, that's right," he'll say. "He's a really dull person." Thus the distinction between writing about a dull person and having a dull piece of writing. I was trying to avoid that in Virgin Time-how to convey the stillness of contemplative prayer without going flat and still.

TIR: I found that some of your writing, maybe especially Virgin Time, made me think of Virginia Woolf. I think it's partly the play you have with the imagination and fact, and partly your spiritual journey. I wondered if you read her works.

PH: I did. Not in college, because she was not really in the works then. She was a more shadow figure. I read the novels late. But I read A Room of One's Own early on, and ended up actually liking Three Guineas better. I thought it was a more complex essay.

TIR: Do you have literary mentors or admired predecessors?

PH: I'd rather talk specifically of daily work, rather than of people I admire, for fear I'll leave out someone I love. I have two kinds of reading that I find useful when I'm working on a project. One I call "starter reading." You know, you wake up in the morning and it seems you've forgotten what writing is. And if you open up a book and you read a few paragraphs, the rhythm of somebody else's prose suddenly reminds you of what writing is 
again. It's like listening-a very particular kind of reading. It can't be something so engrossing that you keep reading all morning and then, Whoops, you haven't done anything. At one point in my life I read Colette a lot, or rather, I read Colette a little, but often. I read her for a page or two, and then I said, Oh right, that's what writing is, and then I'd go to work. When I really started the push for Virgin Time, I picked her up thinking, Well, I'll go back to Colette, but she wasn't my starter reading for that. It didn't work. But James Salter did. So I think there is something strange and mysterious about who can do that for you. Then there's also such a thing, in my mind, as a "companion book." When I was writing A Romantic Education, I came across a book by Michael J. Arlen called Passage to Ararat, which is a story-much of it was published in The New Yorker-of his journey to Armenia. You learn a lot about Armenia, and you also learn a lot about his family life. This was a book that I admired, and I thought I learned from him how to have a grouchy protagonist, yet have an appealing one. He's crabby with his wife, and he 's annoyed with this and that, and yet that annoyance is part of the carrier of the passion for the subject. This was an eye-opener for me. The Snow Leopard, by Peter Matthiessen, was my companion for Virgin Time. I didn't re-read it-or even look at it-while I was writing my own book, but the thought of it heartened me as I worked.

I like reading a writer and feeling I see where he or she has solved a problem. For example, Fierce Attachments by Vivian Gornick, a book about her relationship with her mother, a series of walks through New York City. I met Vivian Gornick about six or eight months after I'd read her book when she came to Minneapolis. "I bet it was a happy day for you when you discovered those walks with your mother," I said. She said, "That's when I knew I had a book." And I knew that's when she knew she had a book too, because I could feel what it must have been like to find that form, to find that shaping thing.

Every book has problems, and how somebody finds a way into the problem is interesting. I often look for that when I'm reading. I also read a lot of poetry and many of the people who matter to me, or are in my mind all the time, are people everybody knows, Whitman and Emily Dickinson. Scott Fitzgerald. The Crack-Up has been very important to me, partly because of its disjunctive nature. I'm very attached to him and to his prose style. I've been teaching memoir a lot lately, so I'm interested in the genre. I like to find out, Where does it come from? Although I can't claim to have 
read all the Confessions of St. Augustine, I like going back there and noting him. And St. Teresa too. I like to find these early examples because I think that the idea of that spiritual impulse retains its power in memoir to this day. Why do we do it this way, why don't we do it some other way? I think there is a spiritual dimension to all autobiographical works whether they call themselves fiction, poetry, or memoir. It is there to-if not save the self, at least to position the self within something larger.

TIR: You've talked about memoir as a quest, and about these books as quests, and you even call them pilgrimages, rather grudgingly.

$\mathrm{PH}$ : Yes, grudgingly is the key word. The language of spirituality often deadens its subjects.

TIR: But in both books you have to travel physically somewhere to recover something from your past. So we were curious, how does travel work with memoir for you? Is it always necessary?

PH: Memoir can't use a plot in the way that a novel seeks a plot. But there has to be some kind of string that you are putting your beads on, there has to be some thing. Clichés get to be clichés for a reason. They've earned their right. The whole idea of our most ancient metaphor, that life is a journey, which is a cliché, is very intimate to our understanding of what it means to be alive, and to live and go from one year to the next. So I think that travel is quite an inevitable part of writing the kind of memoir we're talking about. It takes the place of plot in many memoirs. It creates the sense of a trajectory, of a propelling instinct, of the tensions that plot usually supplies in the novel. I wouldn't say it's absolute by any means, but it seems to be a most congenial form, and you'll see many memoirs imply travel.

One of my favorite memoirs of recent times is Running in the Family by Michael Ondaatje. It's about his trip back to Sri Lanka from Canada to seek his family identity, and his history. He could have done it without the trip, but there's nothing like the body to give you the soul, and that's what you do when you travel. You take your soul into your body and go on the road. That's how we know that something's happening. It's no mistake that Whitman is on the open road, it's no mistake that Jack Kerouac and all that road literature are part of our deepest myth.

TIR: And Dickinson's the opposite.

PH: Yes, Dickinson's the radical opposite.

TIR: With whom you show a little affinity, because you say somewhere in the last section of Virgin Time that the travel has ended. And you also talk 
about the possibility of years passing in a monastery without quite knowing that they would pass, so there must be a bit of the opposite impulse in you somewhere that you are at war with, or-

PH: Given the extreme of anything, you come in touch with its opposite. If you get somebody like Dickinson, hanging out in her father's house in her white dress baking her cakes, or if you get Kafka, sitting in his room, waiting for the world to come to him, what you have is the inversion of travel. Both contemplatives, Dickinson and the nun, Donnie, in Virgin Time, are in fact available for an understanding of their opposites, because there's a pure identity in them. Say you have the traveler on the one hand, and the cloistered soul on the other. What do they remind you of? Each other.

TIR: That works into a tension I feel in both these books. On the one hand, no matter whether you're with people, you're a lone traveler. The journey is personal, and yet you talk about people a lot, and about a people, ethnically and culturally in A Romantic Education, and maybe spiritually in Virgin Time. I'm thinking of the scene at Lourdes where at night you hear the Rosary, and we experience a group transcendental moment with you. I sense a tension in your work between your wanting to be alone and your wanting to identify with some larger group. Am I reading something inPH: No, I think it's true. At the heart of each book is something that's very impersonal seeming. In one book, ethnic identity, in the other, religious, spiritual tradition. Those are abstract subjects. They are also, in their abstraction, something that unites actual living human beings. And dead ones too. They are gathering forces. Even when I was writing $A$ Romantic Education, I knew I had another book, a companion volume, about this religious subject. Another example: If you are a Midwesterner, if that's an identity that partly defines you, if this abstract notion becomes a passionate concern, then you become attached to the lives that have lived that identity. It isn't abstract or theoretical anymore. It is in fact a tent under which a million souls are gathered, many lives, many histories. And that's the spirit, I hope anyway, behind both of my memoirs. The image I had-a funny one-You know the New York Public Library? It has those two lions in front of it? They've each got a name, which I've forgotten, and I always thought I have to write these two books. I didn't know what their titles would be, but one about being Czech and one about being Catholic-those are my lions outside the library. I thought when I finally get those written, 
I can write my real books. I don't know what I thought the real books would be, as if-it was almost as if I had to get past the lions. I had to create the lions and then get past them in order to write the real books. But what are the real books?

TIR: Do you have any clues?

PH: No, that's what seems so strange to me now. What was I thinking those were? They're still ahead of me. I hope.

TIR: Well, you've said in one of your essays that the things you try to elude always wind up claiming you. Both your Czech background and growing up Catholic would be two of those.

PH: For sure.

TIR: Any others?

PH: Well, probably I have another memoir I can imagine writing, that I feel compelled to write. A lot of people can write these other books, but what are the ones I'm supposed to do? That's a good question for a writer to ask. This other memoir is about-maybe-about being a daughter. Provided things go in the natural course and I would outlive my parents, then that would be the time to write that book. Not that there's something I want to say that I couldn't say now-although that must be true too. It's just that the story isn't complete. So I would like to write about that. I could imagine that one.

But there is also the habit of writing. When you have written a long time, it's a habit of your life, and you will find something to write about. It's the thing you do. So whether I write another memoir as my next book or whether I write fiction or whether I return to poetry or write essays doesn't concern me so much as that the project feels like it's my project. Like the thing I should be doing. I remember Isaac Bashevis Singer said that when he got an idea for a story the first thing he did was to try to figure out whose story it was. He went down a number of other Yiddish writers - if it was so and so's story - well, then, he didn't have to write it. But if he got to the end of his list and it was nobody's story, then it must be his story. I feel that a lot of people don't spend enough time thinking about what is theirs to tell. And what can be left for someone else to tell.

This is a very good part of being Catholic, of being brought up Catholic, this whole notion of vocation. You have a real sense that you're supposed to listen for a call. You're supposed to hear what's coming at you. Or coming for you. You're meant to respond to the call. This suits me because 
it takes me so long to do anything. When you consider how thin this book is-so narrow!-it's amazing the fat number of years I had to pour into living it.

TIR: I had an impression from some prior conversation that you were going to do a more complete autobiography of a Catholic girlhood, rather than one such as Virgin Time, which centers on themes, as your chapter headings do, and travel experiences.

PH: I felt that just to go back to a Catholic girlhood was dead material, and not done by the person everybody thinks has done it, namely Mary McCarthy, because in a lot of ways, not only was she generationally of a different experience, but her title is the most Catholic thing about that book. It claims territory that she doesn't in fact develop. So that wasn't it. It was more that I wanted this to be something necessary for today. Not something that was reacting to the past. And I think in some ways I got into some interesting trouble because of that.

TIR: Had people expectations of the book that weren't yours? To be given more spiritual guidance, perhaps?

PH: I've actually had a couple churches call to ask if I would lead retreats! I've had to say, No, maybe I should go on one, but I certainly am not leading anybody else. There's a cottage industry of that sort, disaffected but still searching people, looking for leaders who are not institutional leaders. TIR: You write of prayer in Virgin Time as part of your journey. Is prayer a large part of your life now? Outside of the book that you've written?

$\mathrm{PH}$ : When I go to Mass, there's a line right before Communion-it actually comes from the story of the centurion who asks Jesus to heal his servant-and it says, "Lord, I am not worthy that you should come under my roof, only say the word and my soul will be healed." I always feel a relief when I get to say I am not worthy. It isn't because I think I'm a jerk, it's just that I don't lead the prayer life that I could imagine as the one that would be wonderful to lead.

TIR: There's that wonderful moment in Virgin Time when you are at the monastery and you go up on the hill at dawn to look out over the cut redwoods, and that's your first prayer, which oddly enough is something like, "I can't help it, Lord, this is the way I am." That struck me, the plainness, the simplicity of that.

PH: I think that prayer-when properly understood-is as stunning and compelling, as alarming as poetry, as what we know poetry to be, and to 
be capable of doing. I'm very attached to the Hours, the Divine Office of the Western Church, which moves the way the constellations in the sky do, with different readings for different seasons. There are three different revolving systems of these prayers, mostly Psalms, and every year one of these three great wheels of prayer turns, then you get lifted to the second, and finally you get the third, and then you start over with the first. Daily, weekly, seasonally, and annually, there's this cyclical pattern of prayer. It's a kind of cultural sanity, to have that system of prayer. I think it's remarkable.

I was at St. John's University recently in Collegeville, which is one of the great monastic centers of the world, and I was speaking to a priest up there. Of course, in Catholic life, the Mass is supposed to be the center of liturgical life, and the priest told me that monks talk a lot about how the Mass plays in their lives, and how this cycle of prayer, the Divine Office plays in it, and they all admitted that their real life is over here with this cycle of prayer. While the Mass is important to them, it is not the sustaining life force that the other is. It has nothing to do with belief, by the way. It has to do with practice. Just as the Buddhists talk about practice. It's the same thing, though Catholics tend not to use the word. But you really do see your life change in this patterning. It's fascinating how, if you live long enough, you write enough, you begin to see the seeds of what you do way back. In Woman Before an Aquarium, I have a long poem called "A Time Alone" which takes every hour of the old church pattern, and does a poem on it. And with no idea that I would end up writing Virgin Time. In that same book there's a poem called "My Great Grandmother's Wooden Steamer Case," which I wrote here at Iowa, and it was one of the very few poems that caught anyone's attention-including mine-at that time, and it was about all the material that eventually formed $A$ Romantic Education. So each book started as a poem.

TIR: Were you conscious of working from the poems as you wrote the books?

PH: I was conscious that I'd written the poem in each case, and I got a kick out of the fact that I thought I'd wiped my hands of each subject with the poem, while in fact I'd only identified the task before me.

TIR: I thought that your long poem "Resort" really set up Virgin Time. When you started writing Virgin Time, did you think, Oh, I'm picking up again on- 
PH: No. It was after I'd finished Virgin Time that I saw the connection. In fact, it was just last week, because I was looking at Resort and Other Poems, and I decided to read it, which I hadn't done in years. I read the whole of "Resort," the long poem, and I thought, Oh my God, it's like a blueprint. It had never occurred to me. It was a strange experience to realize the connections between the poem and book. You, as reader, could see the connections quite naturally, but I was blinded by-by the job of writing. I don't think it would have helped me, by the way, to have been conscious of the relationship; I think it would have made trouble. And another thing, if we're talking about to-ings and fro-ings and connections and paradoxes, I'm very aware, now that I've written it, that the impulse behind Spillville was that I had made the trip over to Czechoslovakia, to Prague, and I needed to make the return trip. So I found myself a character-Dvořákwho came the other way, to the Midwest. I was not aware of it at the time I did it; in fact, at the time, I was embarrassed, professionally, that I was returning to an old subject, as if to the scene of an earlier crime. I thought, Oh, here I go again, I don't even know the language, and I'm writing about another Czech subject-a one-note song. But I couldn't help myself, I was compelled by the material. It was only much later that it occurred to me that I'd gotten over there, and now I needed to come back.

TIR: A lot of the things you do write about, especially in Virgin Time, are "beyond words"- you even write that in Virgin Time, the "it" that you're talking about doesn't like words. And yet you manage to write about "it." PH: You get at most things through indirection. When I was a reporter, I asked an old woman some very direct questions as I was interviewing her - this was Meridel LeSueur, maybe you know her-and she said to me, "The Indians never ask a direct question." Which was to say, Quit coming on frontally, and quit interrogating me. Get me to talk, get me to, in a sense, betray myself. That's why there are all those other people in Virgin Time, that's why there are all the Franciscans, why there are all those English agnostics. . . . Because I would not know how to talk about this subject even remotely without borrowing the voices of others. I don't have the experience to talk about being a mystic. So if you feel that something ineffable but real was articulated-I feel lucky that you can say that-I would say it occurs through the voices of other people and through their experience which I rendered as best I could. That's how you do it in literature. It's almost as if you're translating from one language-in this 
case, mystical experience - to another language, which is English. And how do you do that? You know, it's not done directly. It's done with mirrors. TIR: I think of the scene where Sister Bridget and Felix stop by the chapel at night. You're talking about the ineffable "it," but you're making it so homey and intimate-

PH: That's exactly right. And that's how I wanted it to feel. I wanted readers to have that same startling sense that I had when they went into the chapel. If I were to say what I am as protagonist in the book, I would say I'm Toto, the small dog on the road going after the real characters, who are actually living it. I'm panting after them as they go down the road. I'm having the experience, but I am definitely not of their caliber. That has to be. None of us is of the caliber of the experience itself. We're talking about the experience of God. So what I need to do is to make it very clear that I'm a mutt, just panting after this experience in the face ofTIR: Or an apprentice, in a way.

PH: I suppose, but I don't think there's any sense that I'm going to now sign on for the life that they have. I'm very much a secular being, in reality but certainly as the narrator of this book. That's why the notebook has been there all the time as a prop, almost as a character, in the story. Because I'm a writer, and a writer is something different from a contemplative.

TIR: I wouldn't want to accuse you of saying it, but a few times in the book when you're talking about the life of ceaseless prayer, which you sneak up on, and are fascinated by, you're tempted to make an analogy between that and writing and your notebook-your ever-present little book. Would you want to dismiss the analogy, or are you tempted by it?

PH: You know, Kafka said writing is prayer. Where does he say it, I don't know, but he said it someplace. Both have a kind of contemplative quality, no question about it. But they look more alike maybe than they are, finally. Because prayer is lost in the mystery of experience, and writing had better be found on the page, better be found in the hands of other readers, or it doesn't exist. Its world is the world. So it's a different enterprise. It really is different. But they're attached, and I find professional contemplatives certainly understand what it is to write, and to be a writer, more easily than many other artists, even. They certainly understand what it is we do, what it is we're about, and they are absolutely acute readers of poetry. Without any training. Because they read, they pray, poetry every day of their lives. The Psalms, every day. So they know it in a way that a lot of us don't. 
TIR: I've always felt as if I've been looking in the Catholic window. All my relatives are Catholic, except my mother, and grandmother who chose to keep me out of that. I always envied my cousins who got to cross themselves before they dove in the pool, there was the incense in the church and all these beautiful symbols, and my own little stark Methodist churchPH: A cruel fate for a Sicilian.

TIR: - and I was almost ashamed to talk about this aspect of my reading with you, but I'm curious about how you feel about it. At first I felt like your puppy dog, if you're going to use that image, that you were opening up the Catholic door to me, that I wanted a Catholic guide, and you began as my Catholic guide, but at the end became a more pantheistic one. How do you feel about a reader seeing you like that?

PH: Well, it's your book now. And it's probably one of the reasons why - we were joking about it before-why I would never lead a retreat or that kind of thing, because what you do with this book will never harm you, because you can eventually toss it aside. I won't be harmed and neither will you. But the person you choose as a real guide-that is to say, another human being to be your spiritual guide-that's serious, and must not be done lightly. It needs to be an inspired choice. Because such people have enormous power-witness David Koresh, witness Khomeini, witness the Pope. They can be dangerous, so who you choose as your real guide is an important thing. I wouldn't have said this before it had happened to me, but now I can attest to it: when you need a guide, the guide appears. You've heard that line. When I really started seeking, my guide, whom I call Donnie, did appear. And it had nothing to do, in my case, with literature, not that she's illiterate; she's certainly intelligent and well read. But she became that guide person for me. So you see the distinction I'm making between a person as a guide and a book as an experience. You do what you want with that book.

TIR: And I think you've corrected me, too, in that you were not my guide, the book was.

PH: I think so. It's a very different experience. Some writers I know do feel free to mix these two things, but that's not for me. I like to teach, but that's a different thing, I like to teach people about writing, but not about this. I have acquaintances who actually go on the road doing workshops that are about "spirituality," and they make a living, and it's an honest living, and they help people, I guess, but it wouldn't be for me. 
TIR: I think reading is more intimate, somehow.

PH: I do too. I've always felt that. Sometimes somebody'll say, "Oh, do you want to meet so-and-so, a famous writer," and I'll say, "No." All they can do is say, Hello, do you want red wine or white wine. Yet I've had an intimate experience with this person in a book. I don't want to be forced to be superficial. Sometimes the more intimate the book relationship, the less I'm willing to meet at a cocktail-party level. Well, but I'm curious too. I've gone to my share of cocktail parties, I guess.

TIR: But doesn't a book like this-even the cover line describing it as "In Search of the Contemplative Life" -invite a kind of relationship that a lot of books don't? Unlike the others here, I did have a heavy-duty Catholic upbringing, Catholic schools for twelve years-

PH: You're a brave soul to read this book then.

TIR: Well, I did struggle with it, and I was fascinated by how you could go back to what I never did go back to. I was curious about it-I wondered what kind of a guide you'd be if you were a guide, what kind of relationship I'd have with the book. So I'm curious about your response from your Catholic audience. I mean, for me being Catholic is cultural, as much as my ethnicity too.

PH: It hasn't been a unified response, it's been a pluralistic response. We tend to think of Catholicism as such a mono-monster thing. Well, the Pope has not checked in, no cardinal has checked in. But contemplatives seem to be quite excited about the book. Others are annoyed that I don't take on the question of the existence of God more, which I tried early on to explain was not my question, but still, that doesn't mean that I get away with saying that for some people. There have been many responses-positive, negative, indifferent, the whole range. If there's a surprise in this book, it isn't that I rebelled against Catholicism. No surprise there. The surprise is that I went back for more.

TIR: And that's what intrigued me, because I realized there's an element to my spirituality that's missing, that I think about a lot, that I wonder about. But $I$, rigid child of the sixties and seventies, cannot-My political beliefs are still so at odds with the official Church that I have a hard time reconciling them.

PH: Me too. 
TIR: In Virgin Time there's a metaphor of the Church as a large, tumbledown house. And though it's not perfect, people still live there, it's their home.

PH: Let me try a different analogy. This is outside of the book, but inside of the question. I too think of being Catholic as cultural. Culture is everything, as far as I'm concerned. It is the air we breathe, it's the reason we're drinking coffee instead of saki. Being Catholic is for me, in its impossibilities, very much like being American. It is an identity I accept because it seems more true to accept it than not to. Underneath the fairly steady frustrations and shames that come with being a citizen of this rich and powerful country, I feel an ache of love for it. Same with my Catholic heritage. This feeling is a cultural version of what the French call amour propre, which is a wonderful phrase, much better than "self-respect" which has an antiseptic sound. Amour propre is the rightful love of self-or as I'm thinking of it, the proper, inevitable love of country, or love of heritage. It's a kind of acquiescence to one's formation. It's detached-but molten, like the fiery center of the earth which can't be touched but which creates all the life we live here on the surface.

It is an American habit of mind, which I'm going against here, to think that because our whole cultural identity is predicated on individualism, we can decide just about everything. In our minds at least. I can decide whether I believe God exists, and I can decide whether I'm a Catholic or not. I'm going against that grain, admitting that I have been formed by something, and that it is decisive. There's a nun in Virgin Time in the final section, Cecile, I call her. She is a beautiful woman who said that in her twenties she tried a number of Eastern religions and was getting confused because she couldn't keep it all straight, so she decided to go with what she had been born into. Very dispassionate remark there. Not a testament of "faith in Jesus." It is the dispassionate remark of a contemplative looking for a tao, a way, and finding one that at some level was automatic, that she didn't have to learn all over again, learn a whole new cultural system. It was in her. I think that's part of it. I take very seriously the imperatives of culture. I see them as important in literary terms as genetics are in physical terms. Of course cultures permeate each other-just as Eastern religions are touching the West. But the analogy to genetics holds-genes come together to form new bodies.

TIR: In both books you've written what you are, Czech and Catholic. 
PH: I would not have felt I'd done my job if I had merely proved that I could separate myself from Catholicism. What I needed to do was to enter it, being who I am. Probably in the great scheme of things, I suppose I sound closer to an agnostic than any other thing. But most seriously religious people-in distinction to pietistic people-are closer to atheists than to true believers. Religion is about looking for what can't be seen. Yet, I think prayer is the most important thing on earth, and I do believe that it's not a futile exercise. I believe prayer matters, and I do pray, to God-but don't ask me what his address is. Christianity suits me in a lot of ways, imaginatively, because the Incarnation is a fascinating emblem for what happens with mystery: it keeps being born anew. And it keeps being embodied, incarnated, in each life. Inscribed-all those words. For me, again, the guide, and the tao, the way all came together. Most monasteries, most Christian monasteries that I've been to on my various peregrinations for this book have got these prayer cushions, meditation cushions-they're all doing za-zen, they're all formally involved in yoga. I've been to Masses called Zen Masses led by Catholic priests who extend the liturgy into very slow meditative form that you wouldn't recognize. So, the East and the West have met, these things are happening. The point of cultural identity is not to keep one's culture "pure"-but to keep alive within it, as it changes, even as it fades away into something else perhaps.

TIR: That brings to mind Father Andre, from Virgin Time, with his library-Eastern books, Western books, and spiritual books.

PH: Yes, Father Andre with his color-coded books bringing all the searches together in his room. I think resistance to the institutional church and all its repellant macho imperialistic modes and manners, and a simple doubt about the existence of God are part of the experience of spiritual search in our time. I don't think that resistance is the problem, I think it illustrates spiritual search in our age. It's the fundamentalists and the true believers and the people who have it all figured out-those are the scary ones.

Right now I'm editing an anthology for Ballantine of sacred poetry of the West-poems from Islam, Judaism, and Christianity. What Gore Vidal calls the great sky-god religions of the West. Our tradition of monotheism. I've found it very instructive to read my way around our own European tradition with this framework in mind. The biggest surprise is that the modern and contemporary poets seem more religious than any group since the Middle Ages. It's the soupy devotional poetry of the eighteenth and 
nineteenth centuries that cancels out God. The twentieth century atheists are powerfully religious.

TIR: Do you find prayer possible alone, outside of the monastic structure, or the formal help of the Church? When you're home alone, is prayer reachable?

PH: I do think at some point prayer has to be the day itself. It's got to be right this minute.

TIR: One yoga book I've read talks that way too, living every minute as a yoga, or yogi.

PH: Exactly.

TIR: You've used the word tao quite a few times, and thinking back to my reading about Zen and Taoism, I'd say your book feels to me in that third section to be what is called in popular culture "Eastern"-but you've gotten at it in such a Western way.

PH: We deny ourselves so much of our tradition. We're pretty hard on ourselves - for the wrong things. We have a tradition of contemplative life, but because what we think of when we think of the Church is all this rule-making, dogma-chewing, terrible control-making pattern, we go away and we say, Forget it, and then we find some other religion. I find Buddhism very attractive. The only thing is that-I like to read about it, and I like to read from it - but I'm just very attached to my own tradition. It's that simple.

TIR: But incarnation isn't a part of the other traditions that you're speaking of.

PH: There are other ways that they constellate some of the same things. Some people, Allen Ginsberg for example-I spent a day with him last week when I was reading at Brooklyn College-he took me to his apartment and there was his Buddhist altar set up in his bedroom with a picture of Carl Solomon, who had died the previous Sunday. He was the one to whom Howl is dedicated. Allen's a very faithful person, an extraordinary man, and he has taken Buddhist vows. He's very involved at Naropa Institute, which is a contemplative college. But it was much more congenial to him, for mysteries I don't know, and maybe he wouldn't be able to express, to go with this different, very other religion from Judaism, which was what he came from. And Robert Bly once said, "I couldn't stand that repression in Christianity, I just had to go with other things." 
Fair enough. What troubles me sometimes is that people feel that they can't go anywhere, yet they have the desire to take the trip.

TIR: Well, Felix and Bridget don't feel repressed.

PH: No, I didn't think they were.

TIR: Nor does the woman-beautiful Cecile-boy, she doesn't feel repressed either.

$\mathrm{PH}$ : No. She really was just stunning -I kept waiting for central casting to grab her, and not for a nun role either. But these are exceptional people who have a very thick line running down the middle of them that says Contemplative. Most of us have it streaming around in vague patterns in our identities. But for people for whom this becomes a compelling instinct, they're going to find a way to do it, whether they become monks, or nuns, or go to India.

TIR: It seems to me the Church is a broad enough umbrella that you can choose what you're most suited for. For example, in addition to a contemplative history, there's an activist history in the Church that's valid and long lived and anti-authority.

PH: Liberation theology would be one example of that. I went to Naropa a few years ago, while I was doing the research for this book, for a Christian/Buddhist conference. There were contemplatives from the Christian church there, and there were contemplatives from the Buddhists. It was a wonderful, wonderful thing. A Buddhist asked what these two traditions have to offer each other. He suggested that Buddhism can give meditation practice to Christianity. Not that we don't have it, but our contemplative tradition is smudged by the institutional church. What can Christianity, then, give to Buddhism? The answer was-social action. So they will come together, they have to.

My own sense of the imbalance in the West is a little different. Christianity-and by extension, the post-Christian West-needs mainly to be reminded of its own contemplative tradition; Buddhism and other traditions can do that. But what needs to be given to Western culture as it proceeds from its root in the old model of Christendom (and in Judaism, and in Islam) is a model of spiritual life not based on a government model. Christendom has always been the main enemy of Christianity. Religion as imperialism. The fruits of our arrogance and false control are all about us, not the least in our inability to form a coherent public ethic. We don't know what we believe. Tibetan Buddhism-represented at the Naropa 
conference-offers this model. It is based on meditation practice, perhaps. But we need the specifics of that practice much less than we need the lessons of defeat and exile and perseverence-and strength in vulnerability-that the Dalai Lama exemplifies.

There was a wonderful photograph taken of the Pope and the Dalai Lama embracing in Assisi at a world conference on peace. There's the Pope, all decked out in heavy white, completely cloaked, frosted practically. The Dalai Lama, in a silky saffron robe with his shoulder and arm exposed, has thrown himself into the stiff arms of the Pope. That's what we need from Buddhism, from other spiritual traditions-this picture of embrace, of spontaneous engagement. In the picture, the Dalai Lama looks delighted, joyful. The Pope looks a bit stunned, sort of astonished. I suppose Western culture is in for a period of astonishment.

Maybe it's just a quirk of personality that I've felt compelled to go back to the Catholic tradition, but it fits with everything else, with all the going back-nesses that I do in my writing and in my life, and all my hanging in with old St. Paul, my hometown. But it certainly isn't the only way to skin this cat. If somebody had told me ten years ago that I would be blocking off in my calendar times of the year to be at the monastery for Holy Week-there would be absolutely nothing I would ever do to miss long periods of time at the monastery during Holy Week and during Advent-I would've thought, You're out of your mind, out of your mind. Or I would have to be knocked off my horse on the way to Damascus for such a thing to happen. And neither of those things has happened. But just as the Buddhists talk about a practice, this is a practice. Nothing more, nothing less. It's no big deal. Though it's huge.

TIR: The things that I read in the seventies always said that when we reach the true spiritual time it's going to be East and West coming together.

PH: Whitman says it too, it seems to me, somewhere. Didn't he say just about everything? And I think Emily Dickinson said the rest of it.

TIR: One of my favorite books is a book by a French priest who served in India and got fascinated with yoga in the fifties and wrote about it in the early sixties. Two books. One is called Yoga in Ten Easy Steps, and the other is called Christian Yoga, which is an amplification of the first book. And he feels apologetic for having to confess an interest in yoga and defend it as part of a Christian spiritual life. He always talks about how every position you take celebrates prayer. At the end of holding a posture you might pray 
better, have more peace to pray. It wasn't that long ago, in the sixties, that he had to defend the license he was taking by learning from yoga.

PH: It would be very interesting to know what would have happened to Thomas Merton had he lived. He was in Thailand, and he was meeting all these Buddhist monks, and I think his Asian Journals is an interesting book. It's a fascinating account of a man encountering all kinds of other practitioners of the same art form and the same practice. He's doing the Christian thing, they're doing their version of it, and they're connecting and they can talk to each other.

One thing that isn't in our conversation is that there is in contemplative life, just as there is in art itself, in that very intimate act, the seeds of social connection and social commitment. I don't think it unusual that contemplatives, Buddhists, Christians, or otherwise, burned themselves in front of the United Nations and the American Embassy in Saigon, or that a Quaker named George Morrison did the same thing during the Vietnam War. Or that contemplatives find themselves getting into all sorts of frays, and sometimes give their lives, but certainly give their energies, to social action. There is a connection between action and contemplation. They're not opposites. They're not paradoxes. So that all of this seeming personalism, or interiorism - of the memoir, on the one hand, which I think belongs not to the self but to history, or of contemplative life, which seems to be alone in a room but really connects with the life of pain and suffering-both of these things have what might be called a political component. I think that's a really important feature of both, and why they are of value, and why they are of use. Otherwise they are empty forms.

TIR: Emily Dickinson can imagine the world from her room, right? And help us in it.

PH: Yes. To me it's evident-it doesn't need saying-but in another way, as I'm recasting my mind over all we've said today, it seems that's something that didn't get put in.

TIR: I'm glad you said it. I find things that I read today seem so without spirit, without any spiritual life, and maybe it's because we've come to believe that politics and religion, or politics and spirituality are opposite, and if we want political action we've got to step down from the spiritual, so I'm glad you're seeing them together that way. I don't think I've read about the soul since Virginia Woolf. Maybe it's just my limited reading, but 
it almost gets to be a nasty word. I think we were embarrassed for a while to even use a word like "soul" in literature.

PH: I was speaking at St. John's University to a woman who teaches there. She's a scholar, not Catholic, gay, living with her partner, and not from Minnesota, therefore seemingly on the outs of this culture where she finds herself. I asked her, "What do you make of this? Do you feel a little stifled here?" She had the answer right away, didn't miss a beat. "Absolutely not. I came here from a state university, I feel much freer here. I know, it doesn't make any sense. But I can talk about the human spirit, I can use that phrase here. I can talk about the soul, or the spirit, I can say those words here, use them in discussing literature, and I'm not seen as a weirdo. Nor do I censor myself. I would censor myself elsewhere, or many elsewheres. I feel I can bring more of life into the classroom." She's at a Catholic university, but she's not a Catholic, I don't know what her religion is, or if she claims one. But she has a soul-and speaks to other souls. She knows that is her work, what she must do. 